\title{
Review
}

Stereotactic

and Functional

Neurosurgery
Stereotact Funct Neurosurg 2014;92:269-281

DOI: $10.1159 / 000364914$
Received: January 7, 2014

Accepted after revision: May 30, 2014

Published online: September 18, 2014

\section{The Neurosurgical Treatment of Alzheimer's Disease: A Review}

\author{
Adrian W. Laxton ${ }^{a}$ Scellig Stone ${ }^{b}$ Andres M. Lozano ${ }^{b}$ \\ ${ }^{a}$ Department of Neurosurgery, Wake Forest Baptist Medical Center, Wake Forest University, Winston Salem, N.C., \\ USA; ${ }^{b}$ Division of Neurosurgery, Toronto Western Hospital, University of Toronto, Toronto, Ont., Canada
}

\section{Key Words}

Alzheimer's disease - Deep brain stimulation .

Neurosurgery · Therapy effects · Cognition

\begin{abstract}
Background: Alzheimer's disease (AD) is a debilitating neurological illness of increasing prevalence. Because many patients are affected and current treatments have limited effectiveness, other therapeutic strategies are urgently needed. Objectives: Here we provide a review of the neurosurgical approaches that have been attempted or are currently being investigated for the treatment of AD. Methods: Computerized database searches identified all of the published studies in the English-language literature examining the surgical treatment of AD since 1950. Results: The following 5 categories of neurosurgical treatment were identified: cerebrospinal fluid shunting, intraventricular infusions, tissue grafting, gene therapy, and electrical neural stimulation. Conclusions: While none of the neurosurgical approaches applied to the treatment of AD have proven effective to date, recent trials involving gene therapy and electrical neural stimulation are showing promising early results. Larger trials investigating these treatments have been proposed or are currently under way.

(c) 2014 S. Karger AG, Basel
\end{abstract}

\section{KARGER}

E-Mail karger@karger.com

www.karger.com/sfn

\section{Introduction}

The field of neurosurgery has traditionally focused on the identification and elimination of structural pathologies in the brain and spine. More recently, however, neurosurgeons have made important contributions to the treatment of functional neurological disorders. Deep brain stimulation (DBS) has become a well-established therapeutic modality in the treatment of some movement disorders, and it may also have a role in the treatment of certain neuropsychiatric conditions [1-3]. Perhaps less well known, however, is that over the past 40 years neurosurgeons have also attempted to apply neurosurgical approaches to the treatment of dementia, and specifically Alzheimer's disease (AD). In this paper, we review the published literature examining the neurosurgical treatment of AD in humans.

\section{Methods}

The primary literature search was made using Ovid OLDMEDLINE 1950-1965, Ovid MEDLINE 1966-2012, Ovid MEDLINE Corrections, Ovid MEDLINE in Process and Other Non-Indexed Citations, EMBASE (Excerpta Medica Database), and All EBM (Evidence-Based Medicine) Reviews (Cochrane Database of Systematic Reviews, American College of Physicians Journal Club, Database of Abstracts of Reviews of Effects, and Cochrane Central Register of Controlled Trials). The search terms were as follows: 'Alzheimer' OR 'dementia' AND 'surg' AND 'tri- 
Table 1. Categories of neurosurgical therapy applied to the treatment of $\mathrm{AD}$

\section{CSF shunting}

Intraventricular infusions

Tissue grafting

Gene therapy

Electrical neural stimulation al' OR 'treatment' OR 'therap' (all terms in title or abstract). Then a search using the MESH headings 'Alzheimer, surgery' and then 'Alzheimer, drug therapy' was made using PubMed. This yielded a set of relevant articles. The reference sections of each of these articles were then examined to find pertinent articles not identified with the original database searches. These articles were then entered into the Web of Science to identify articles that had cited them. Finally, PubMed searches were conducted with the search terms 'shunt', 'infusion', 'omentum', 'transplantation', 'gene therapy', 'vagus nerve stimulation', and 'deep brain stimulation', along with 'Alzheimer' and 'dementia'. With each search, the PubMed function 'Related Citations' was used to identify any other potentially relevant studies.

The literature search outlined above identified 24 articles describing trials of surgical AD treatments with human participants. These trials can be divided into the following 5 categories of surgical approaches: cerebrospinal fluid (CSF) shunting [4-7], intraventricular infusions [8-16], tissue grafting [17-19], gene therapy $[20,21]$, and electrical neural stimulation [22-26] (table 1). The specific treatment strategies within each category are described in detail below (table 2).

\section{Published Human Trials of Neurosurgical Treatments for AD}

\section{CSF Shunting}

Interest in the potential benefits of CSF shunting for the symptomatic treatment of patients with dementia arose after the work of Adams et al. [27]. They were the first to propose the dementia syndrome of normal pressure hydrocephalus and to describe how it could be treated with CSF shunting. Following the report of Adams et al, Appenzeller and Salmon [4] and Salmon [5] described the use of ventriculoatrial shunting to treat patients with cerebral atrophy and dementia. The postulated rationale for this intervention was that, by lowering intracranial pressure, CSF shunting could enhance cerebral blood flow and thereby increase nutrient support to degenerating but still partly functional neurons. Although the authors claim that CSF shunting was beneficial to these patients, methodological deficiencies, including participant heterogeneity, subjective outcome measures and a brief follow-up interval, limit the interpretation of these studies.

More recently, Silverberg et al. [6] revisited the potential for CSF shunting to treat AD. The rationale for this work was based on research showing abnormal clearance of tau and $\mathrm{A} \beta$ proteins in the CSF of $\mathrm{AD}$ patients [28]. By increasing CSF clearance, Silverberg et al. [6] hypothesized that shunting could help to clear these toxic proteins and thereby slow or stop the progression of disease. After a promising pilot study [6], a larger, multicenter, randomized, double-blind, placebo-controlled, clinical trial involving 215 participants was halted for futility after it was unable to show any benefit with treatment [7]. Interest in CSF shunting for AD has since waned.

\section{Intraventricular Infusions}

Several agents have been infused into the cerebroventricular system of AD patients in an attempt to treat the condition. The substances that have been used in human trials can be divided into 2 categories: cholinergic agents (bethanechol chloride and nerve growth factor, NGF) and neuroprotective factors (monosialotetrahexosylganglioside, GM1).

\section{Bethanechol Chloride}

Harbaugh et al. [12] reported the first attempted therapeutic infusion of a cholinergic agent into the CSF of AD patients. The rationale for such an approach was based upon the cholinergic hypothesis [29] that decreased synthesis of acetylcholine is a fundamental neurochemical factor related to the cognitive deficits in AD. Bethanechol chloride, a water-soluble muscarinic agonist, was delivered using a fully internalized, continuous infusion device. This initial trial was then soon followed by similar studies conducted by Penn et al. [13] and Read et al. [14]. In these studies, intraventricular bethanechol chloride commonly induced nausea with no clear therapeutic benefit. Harbaugh [10] and Harbaugh et al. [11] went on to conduct a larger placebo-controlled, double-blind, single crossover study and found that intraventricular bethanechol chloride did not produce clinically meaningful improvements in AD. No further studies investigating this therapeutic strategy have been published.

\section{Nerve Growth Factor}

The next agent to be tried was NGF. Exogenously delivered NGF has been shown to rescue compromised cholinergic neurons and reverse memory impairments in animal studies [30, 31]. Given that the remaining choliner- 
Table 2. Summary of neurosurgical trials for $\mathrm{AD}$

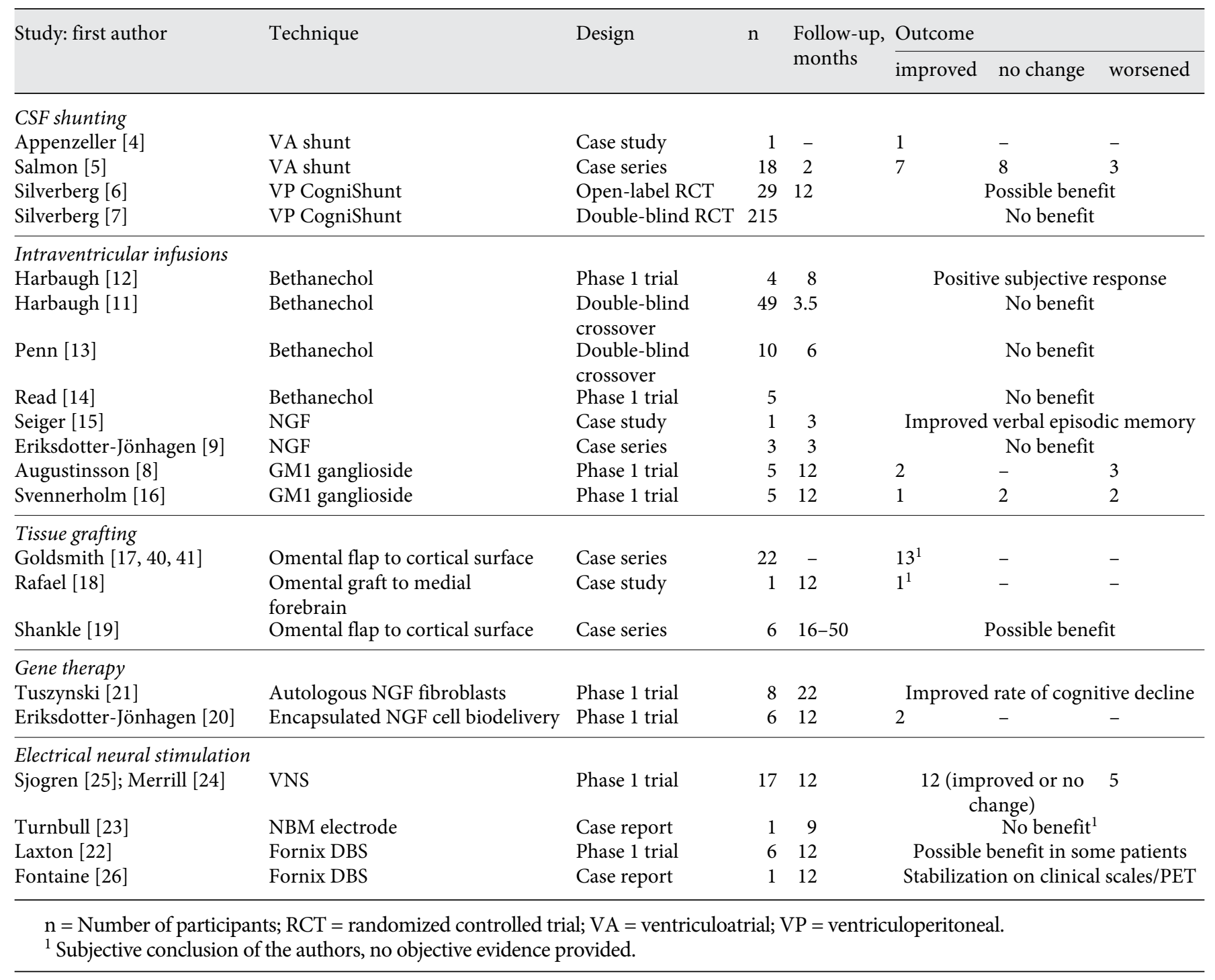

gic neurons in $\mathrm{AD}$ patients are known to express NGF receptors, and that intracranial NGF infusion had already been performed in a small number of Parkinson's disease (PD) patients, the stage was set for an attempt in $\mathrm{AD}$.

In 1993, Seiger et al. [15] published the first use of intraventricular NGF infusion to treat an $\mathrm{AD}$ patient. A follow-up study by the same group in 1998 reported 2 additional patients along with their previously published case [9]. Side effects of treatment, in particular pain, weight loss, insomnia, anxiety, and confusion, were a significant issue in all 3 cases. The lack of clinical efficacy and prominent side effects make intraventricular NGF infusion an unsuitable therapy for $\mathrm{AD}$ patients.

\section{GM1 Ganglioside}

A third strategy for the treatment of AD using intraventricular infusion was reported by another group in Sweden in 1997 [8]. This group had been investigating the use of gangliosides, abundant neuronal plasma membrane components, for the treatment of AD. Experimental evidence shows that gangliosides can have neuritogenic and neuronotrophic properties [32-34]. After the failure of an open-label study delivering the ganglioside GM1 parenterally to $\mathrm{AD}$ patients [35], the researchers initiated 2 studies of intraventricular GM1 infusion combined with a cognitive training program $[8,16]$, suggesting that GM1 infusion may be therapeutically useful for 


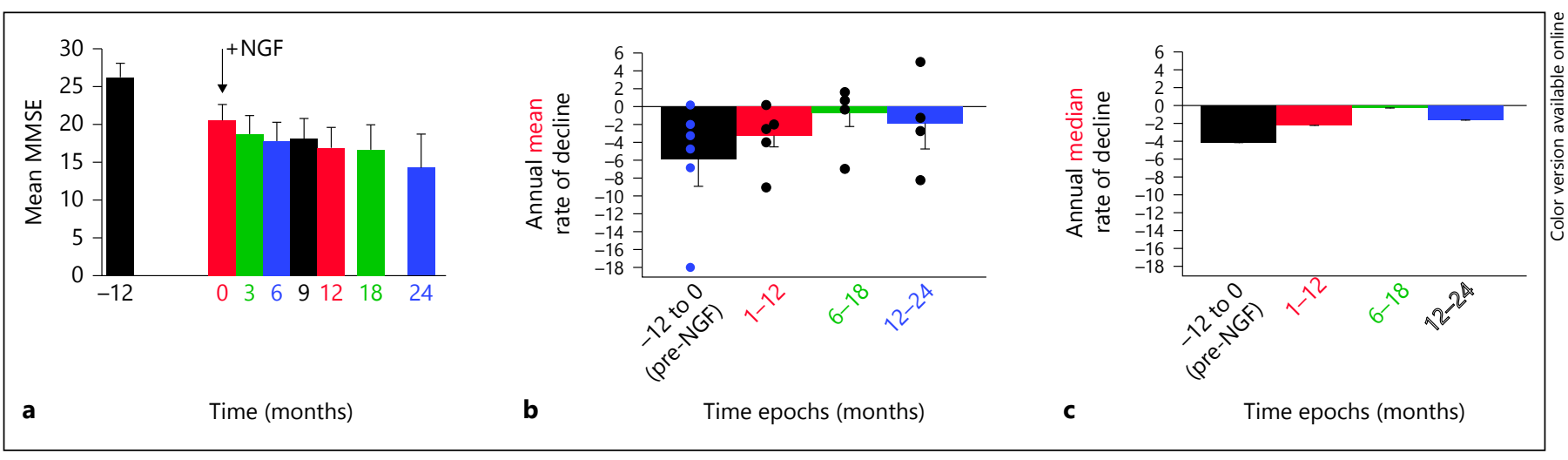

Fig. 1. a Mean total MMSE scores before and after NGF treatment (error bars, SEM). b Mean annualized change in MMSE score in the year before treatment and in time epochs of 1-12, 6-18 and 12-24 months after treatment. c Median MMSE scores are also shown. Reprinted with permission from Tuszynski et al. [21].

$\mathrm{AD}$ patients. Ultimately, however, the design of both studies precludes any determination of causality between the surgical therapy and outcomes, and does not rule out the possibility that the clinically relevant therapeutic intervention was in fact related to other factors such as the associated training program.

\section{Tissue Grafts}

\section{Omentum}

Based on animal studies demonstrating increased cerebral blood flow with omental autografting to the cortical surface of the brain [36-38], Goldsmith et al. [39] have proposed the therapeutic application of omental grafts for human conditions associated with cerebral ischemia. Postulating that the neuronal degeneration of $\mathrm{AD}$ could be related to decreased cerebral blood flow, Goldsmith [17, 40], Goldsmith et al. [41], Rafael et al. [18], and Shankle et al. [19] have investigated whether omental grafts could slow or reverse AD-related cognitive decline in small case series. As Goldsmith [42] has acknowledged, however, a more rigorous, prospective, controlled study will be necessary if omental grafting for $\mathrm{AD}$ is to be considered a viable therapeutic option.

\section{Neural Tissue}

Although transplantation of neural tissue has been proposed as a potential treatment option for $\mathrm{AD}$ [43], no human trials have yet been reported.

\section{Gene Therapy}

Targeted gene therapy is an emerging therapeutic approach in neurosurgery for a range of neurological disorders, including brain tumors [44], PD $[45,46]$ and AD
$[20,21]$. A considerable amount of preclinical research shows that NGF stimulates cholinergic function, prevents the degeneration of cholinergic neurons and enhances memory [30, 31, 47].

Tuszynski et al. [21] performed the first therapeutic trial of targeted NGF gene therapy in AD patients. They employed an ex vivo technique in which the patients had their own genetically modified NGF-secreting fibroblasts stereotactically implanted into their basal forebrain. The patients' scores on the Mini Mental State Examination (MMSE) [48] and on the Alzheimer's Disease Assessment Scale - cognitive subscale (ADAS-Cog) [49] showed an improved rate of decline (fig. 1,2). Furthermore, whereas progressive decreases in neocortical glucose metabolism are expected in $\mathrm{AD}$ patients, serial 18-fluorodeoxyglucose (FDG) PET scans in 4 of the subjects showed significant increases in neocortical glucose metabolism at 6-8 months after treatment, particularly in those regions known to receive cholinergic basal forebrain projections (fig. 3).

Building on this ex vivo NGF gene therapy technique, Bishop et al. [50] have developed an in vivo approach using the CERE-110 adeno-associated virus-based (AAV2) human NGF gene delivery vector. A phase 1 clinical trial of CERE-110 (AAV2-NGF) gene therapy in human AD patients has been conducted (NCT00087789) [51] and a double-blind, sham surgery-controlled, phase 2 study is ongoing (NCT00876863) [50].

Similar to the ex vivo genetic modification of autologous fibroblasts to produce NGF developed by Tuszynski et al. [21], Eriksdotter-Jönhagen et al. [20] and Wahlberg et al. [52] have developed an encapsulated cell biodelivery technique using cells genetically modified to secrete NGF. 


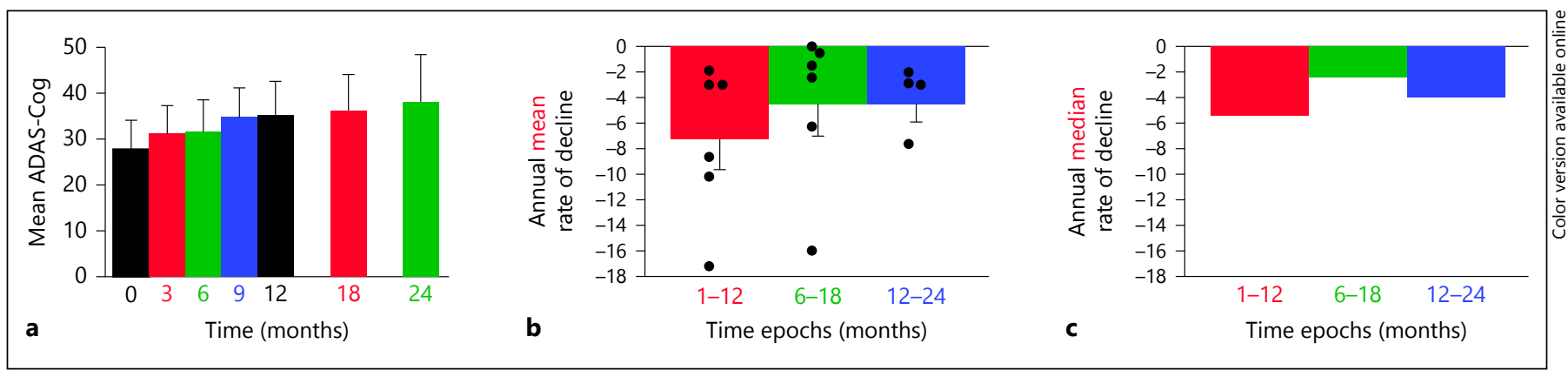

Fig. 2. a Mean total ADAS-Cog scores 2 weeks before NGF and subsequently (error bars, SEM). b Mean annualized changes in ADASCog over time epochs of 1-12, 6-18 and 12-24 months after treatment. c Median ADAS-Cog scores are also shown. Reprinted with permission from Tuszynski et al. [21].

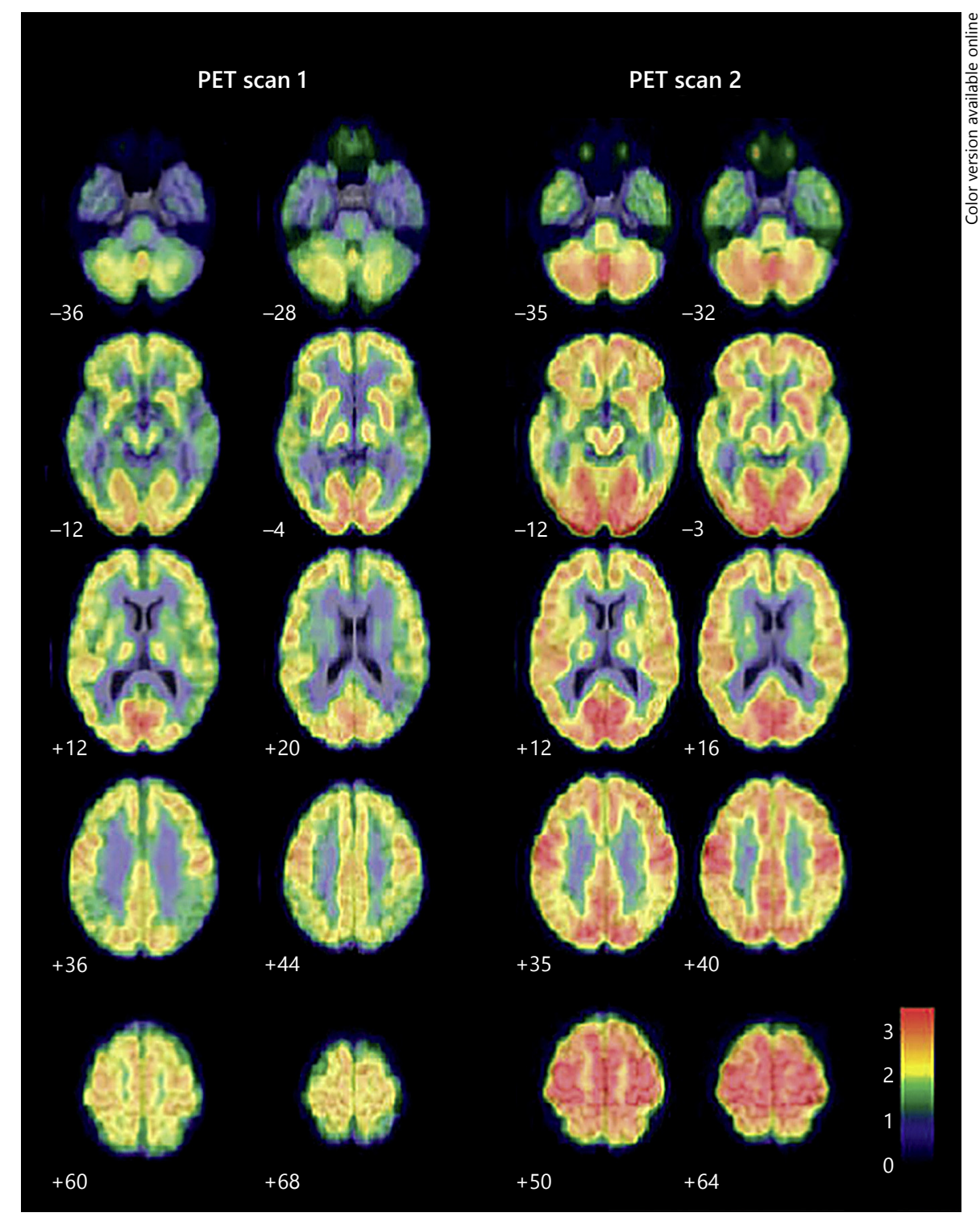

Fig. 3. Averaged FDG PET scans in 4 subjects treated with NGF, overlaid on standardized MRI templates. Flame scale indicates FDG use/100 g tissue/min; red color (color in online version only) indicates more FDG use than blue color. Reprinted with permission from Tuszynski et al. [21]. 
The encapsulated cell biodelivery implant consists of a genetically modified NGF-secreting human cell line encapsulated behind a semipermeable hollow fiber membrane that allows the influx of nutrients and the efflux of NGF. A total of 6 AD patients were enrolled in this openlabel phase 1 study. The surgical procedure was performed successfully in all patients, with no serious adverse events. The authors reported positive findings in cognition, EEG and nicotinic receptor binding in 2 of 6 patients. The usefulness of this approach will require further study.

\section{Electrical Neural Stimulation}

Over the past 20 years, the clinical application of electrical neural stimulation has advanced dramatically. Two prominent modalities of clinical neural stimulation are vagus nerve stimulation (VNS), used to treat epilepsy and depression [53], and DBS, which has become an established treatment for the motor manifestations of movement disorders such as PD, dystonia and essential tremor [54-61].

In addition to their local effects, these therapies modulate the downstream neuronal circuits functionally connected with the stimulated target structures [62-67]. These widespread circuit effects are important as they relate to an emerging conception of the pathogenesis of neurodegenerative disorders such as $\mathrm{AD}$. The pathological processes in specific brain areas that occur in $\mathrm{AD}$, such as the nucleus basalis of Meynert (NBM) and the entorhinal cortex, create abnormalities that affect not only the immediate structures involved but also the downstream areas that receive inputs from them within a network of functional connectivity [68]. Thus, $\mathrm{AD}$ is associated with default mode network dysfunction [69] and abnormalities in glucose utilization across wide cortical and subcortical areas $[70,71]$. Because AD can be considered a brain circuit dysfunction disorder and the clinical rationale of electrical neural stimulation is the modulation of neuronal circuits, both VNS and DBS are being investigated for the treatment of $\mathrm{AD}[22,24,25,72]$.

\section{Vagus Nerve Stimulation}

The possibility that VNS could enhance cognition and memory performance was first demonstrated in animal studies $[63,73]$ and then in a group of depressed patients [74]. These studies provided the empirical rationale for a trial of VNS in AD patients.

Sjogren et al. [25] and Merrill et al. [24] conducted 2 studies to assess the effect of VNS on cognition in $\mathrm{AD}$ patients. After 1 year, 12 of 17 patients improved or did not decline from baseline on the ADAS-Cog and MMSE. In addition, 12 of 17 patients showed no change or some improvement from baseline on the Clinician InterviewBased Impression of Change (CIBIC) scale [75]. Controlled studies of VNS for AD are needed.

\section{Nucleus Basalis of Meynert DBS}

Neurodegeneration in the NBM and dysfunction in its associated neuronal circuitry are key pathological features of $\mathrm{AD}$. Turnbull et al. [23] were the first to report the effects of NBM DBS in an AD patient. These researchers implanted a DBS electrode in the patient's left NBM.

The authors reported no clinical benefit with stimulation. Stimulation did affect cerebral glucose metabolism, however. Using FDG PET scans, the researchers compared the changes in glucose utilization over time in the patient's unstimulated right hemisphere with his stimulated left hemisphere. In the patient's right hemisphere, glucose utilization in the frontal, temporal, parietal, and occipital lobes decreased by $21,24,10$, and $7.5 \%$, respectively. In contrast, glucose utilization in the stimulated left hemisphere decreased by only $12 \%$ in the frontal lobe and $4.1 \%$ in the occipital lobe, showed no change in the parietal lobe and actually increased by $1.5 \%$ in the temporal lobe. Despite demonstrating that NBM DBS can be performed safely and produce a robust, pathophysiologically relevant biological effect, the authors did not pursue further investigations of this therapy.

More recently, Freund et al. [76] investigated the effects of NBM DBS in a 71-year-old man with dementia associated with PD. To address both the motor and cognitive aspects of his condition, the patient underwent stereotactic insertion of bilateral subthalamic nucleus (STN) and NBM DBS electrodes. STN DBS was initiated first and maintained throughout the study. The patient's motor function improved with STN DBS, but his cognitive impairment remained unchanged. After NBM stimulation was initiated, the authors reported that the patient exhibited a marked improvement in his overall cognitive function, as measured by the Rey Auditory Verbal Learning test, the Clock Drawing task and the Trail Making task - part A. As a further test of the NBM DBS effect, the researchers subsequently turned off the stimulator for 1 week without informing the patient, and then turned it back on. When the NBM DBS was off, the patient returned to his baseline state of dementia. Then, with NBM DBS back on, the initial gains in cognitive function were reestablished.

In a separate paper, the authors report the patient's improvement in praxis with STN and NBM stimulation [77]. Prior to surgery, the patient was unable to demon- 


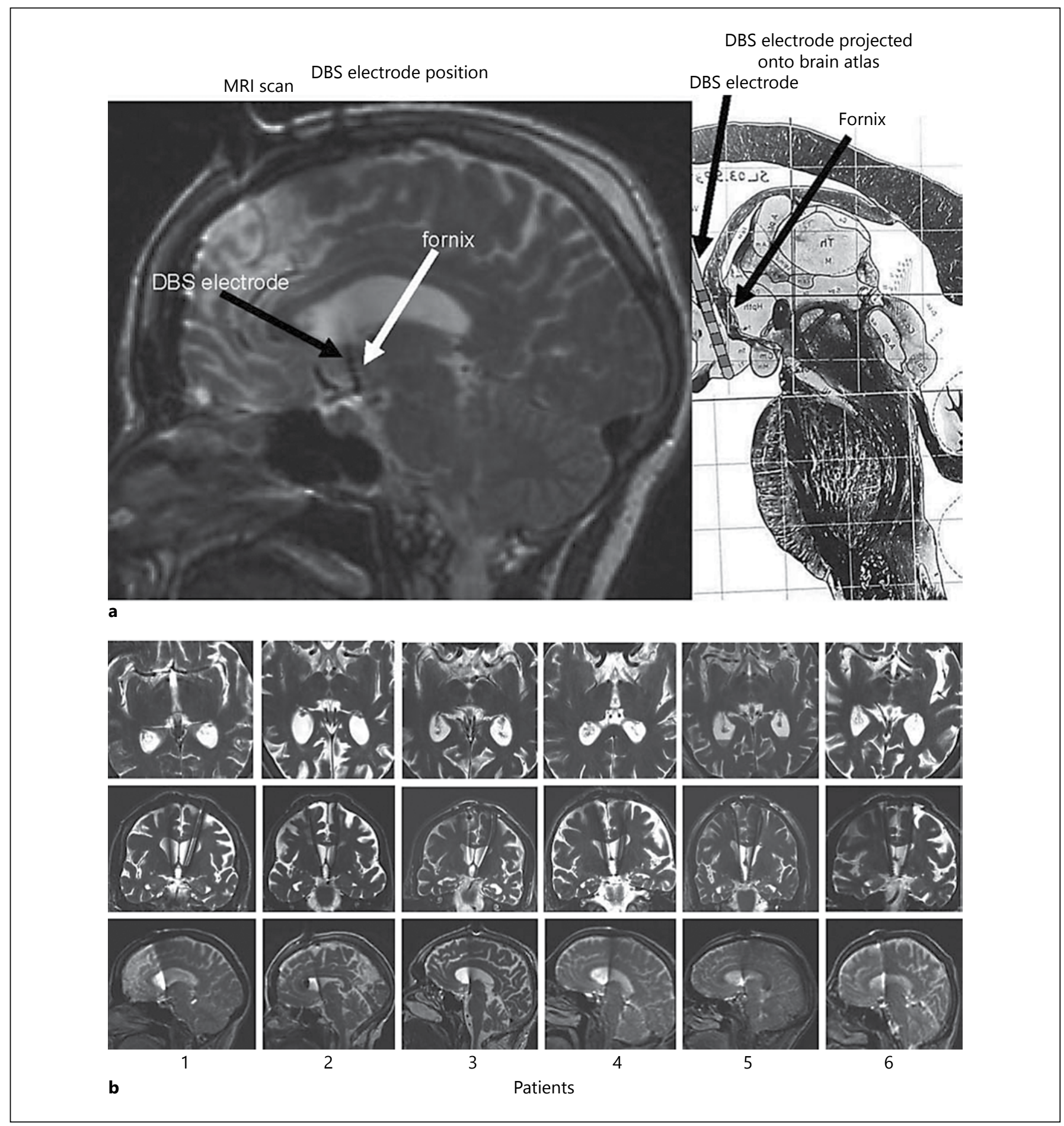

Fig. 4. a Location of DBS electrode in a sagittal MRI (left) and projected onto a stereotactic atlas $3.5 \mathrm{~mm}$ from the midline (right). The electrodes were positioned immediately anterior and parallel to the vertical segment of the fornix within the hypothalamus. Each electrode has 4 stimulation contacts. The ventral-most contact, desig- nated contact 0 , was in proximity to the optic tract and anterior to the mammillary bodies. $\mathbf{b}$ T2-weighted or proton density MRIs of $6 \mathrm{AD}$ patients showing the position of the fornix/hypothalamic DBS electrodes in axial (top), coronal (middle) and sagittal (bottom) planes. Reprinted with permission from Laxton et al. [22]. 
Fig. 5. a Decrease in individual MMSE scores in 6 patients in the 11 -month period before surgery compared to the 11-month period after DBS surgery. A negative score indicates an increase (improvement) in MMSE. Individual bars before and after surgery correspond to patients $1-6$ in sequence. b ADAS-Cog scores in $6 \mathrm{AD}$ patients at baseline or after 1,6 or 12 months of DBS. The last point on the graph represents the predicted 12-month ADAS-Cog score as predicted on a regression formula based on a meta-analysis of $>50$ studies [86]. Reprinted with permission from Laxton et al. [22].

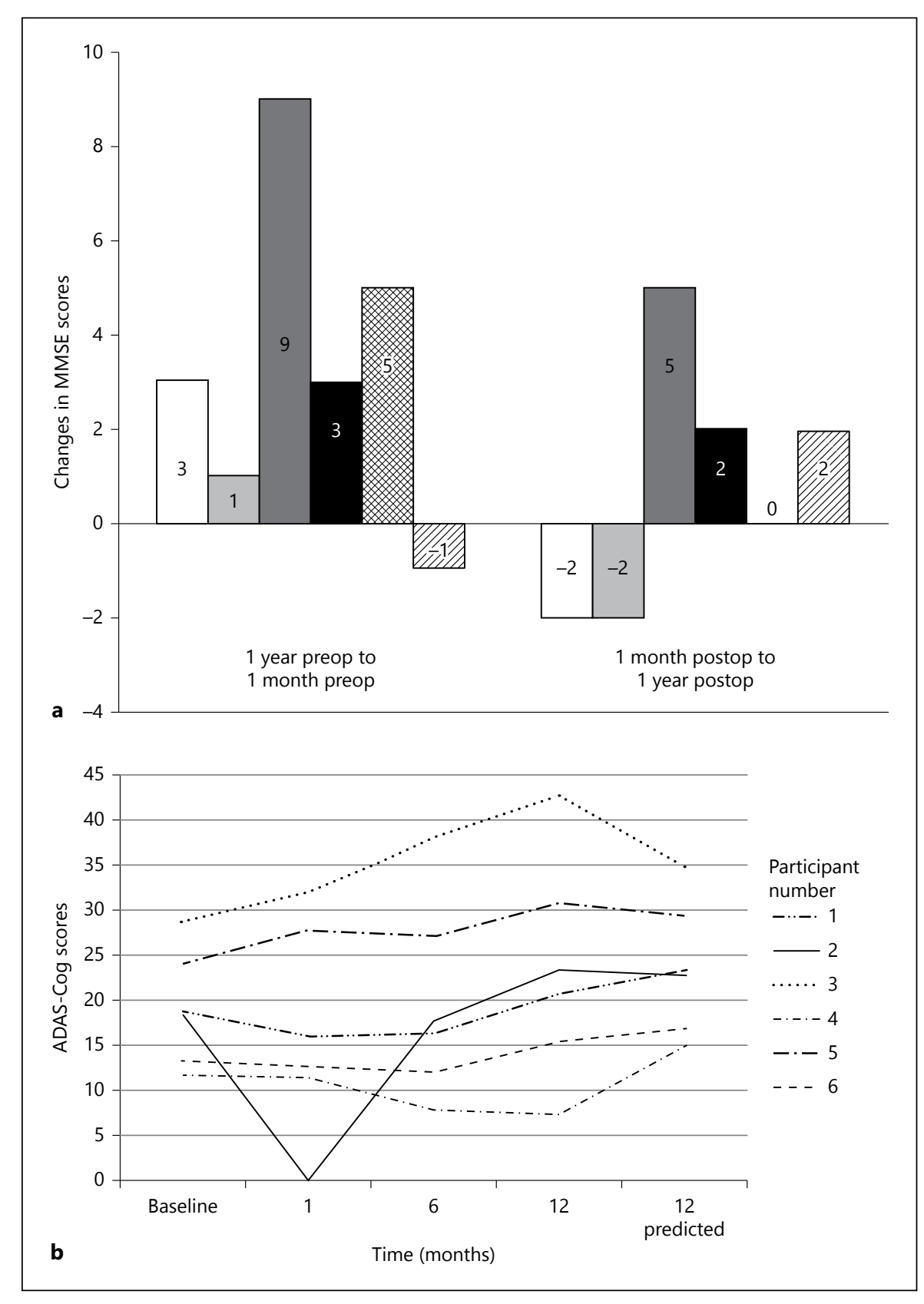

strate how to brush his teeth, how to use a hammer or how to wind a watch, whether he was given verbal instructions or shown the behavior and asked to imitate it. With STN and NBM DBS on, he could perform these behaviors quickly and efficiently.

Based on these results, the authors concluded that NBM DBS had a broadly positive effect on their patient's cognitive function, although this effect was not specific to memory and may reflect a more general 'tuning' of the widespread neocortical projections of the NBM. Their re- sults are intriguing and warrant the continued investigation of NBM DBS for the treatment of dementia, including AD. This group of researchers is currently conducting a trial of NBM DBS for AD (NCT01094145).

\section{Fornix DBS}

The fornix is a fundamental structure in the neuroanatomy of declarative memory, and fornix lesions produce memory impairments [78-80]. Axonal degeneration and dysfunction in the fornix are believed to contrib- 
ute to the pathogenesis of AD [81]. Fornix DBS has been shown to enhance memory in rodent models of cognitive impairment [82].

The potential for fornix DBS to enhance memory in a human has recently been examined by our group [83]. We speculated that this approach could be applied to drive neurophysiological activity in patients with dementia and, on this basis, conducted a phase 1 clinical trial of fornix DBS in AD patients [22].

A total of 6 patients with early $\mathrm{AD}$ were enrolled in the study (fig. 4). The surgery and chronic fornix stimulation were safe and well tolerated in all patients. Although the small sample precludes definitive statements regarding possible efficacy, there was suggestive evidence from sequential MMSE and ADAS-Cog assessments that the rate of cognitive decline may have improved in some patients relative to baseline and to historical controls [84] (fig. 5). The physiological effects were more impressive, however. Fornix stimulation produced direct and transsynaptic sequential activation of downstream targets along the wellcharacterized connection pathways between the fornix and hippocampus that underlie declarative memory function. FDG PET scans showed a pattern of increased temporoparietal glucose metabolism that was maintained with chronic fornix DBS up to 1 year after surgery [85] (fig. 6). These results indicate that fornix DBS produced large and sustained changes in cognitive and limbic brain areas known to be adversely affected in AD.

Similar findings have been reported by a separate group in France [26]. In a single patient with early AD, it was found that clinical measures of cognition and memory, as well as cerebral glucose metabolism, stabilized for up to a year following the initiation of chronic bilateral fornix DBS.

A double-blind, controlled phase 2 trial of fornix DBS for $\mathrm{AD}$, in which participants are randomly assigned to early versus 6-month postoperative initiation of stimulation, is currently under way (NCT01608061).

\section{Mechanisms of DBS for AD}

As described above, functional neuroimaging has shown that DBS in AD patients drives neural activity rather than suppresses it. The mechanisms by which DBS influences neural activity are complex and multifactorial [for a detailed review, see 86]. Electrode configuration, parameter settings and stimulation timing influence the effect of DBS. At very high current settings, anterior nucleus of thalamus DBS can impair memory performance in rodents [87]. However, when the electrode, parameters and timing are correct, stimulation can enhance memory
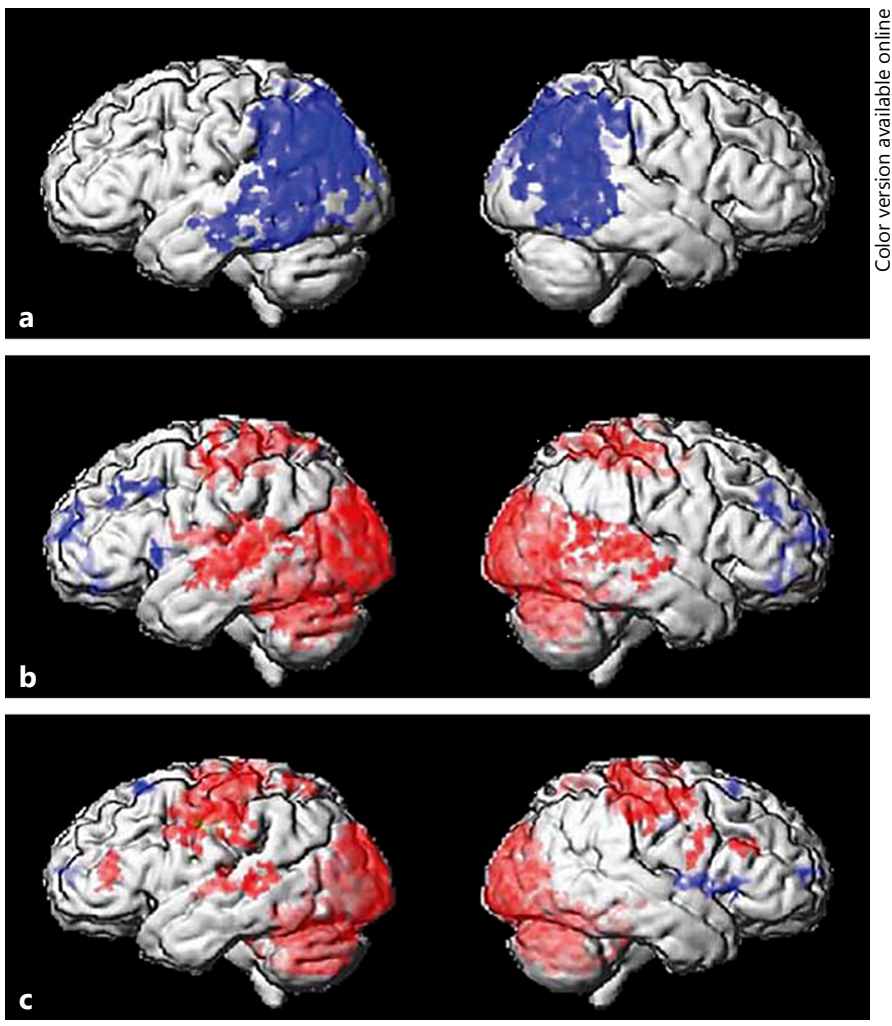

Fig. 6. PET scans of glucose metabolism. Voxel-wise (SPM5) results are displayed on a 3D MR rendering of a representative subject for the comparison of AD patients to controls (a), 1 month of DBS to baseline (b) and 12 months of DBS to baseline (c). The metabolic values that are shown are scaled to $\mathrm{mg} / 100 \mathrm{~g}$ tissue/min; blue color represents areas of decreases and red indicates areas of increases in glucose metabolism. Reprinted with permission from Laxton et al. [22].

and cognitive function, as has been demonstrated in animal studies using anterior nucleus of thalamus [88], entorhinal cortex [89], hippocampal [90], fornix [82], and dorsolateral prefrontal cortex stimulation [91].

An intriguing potential mechanism by which DBS may influence memory has recently been identified: hippocampal neurogenesis. The promotion of neurogenesis has been demonstrated in rodent studies involving the electrical stimulation of the anterior nucleus of thalamus $[88,92,93]$, hippocampus $[94,95]$ and entorhinal cortex/ perforant path $[89,96,97]$. Researchers investigating the functional significance of stimulation-induced neurogenesis have found compelling memory effects. Both entorhinal cortex [89] and anterior nucleus of thalamus [88] stimulation can enhance memory in rodents. However, when neurogenesis is blocked by temozolomide, or when memory testing occurs before new neurons can mature, 
stimulation is not associated with memory enhancement. Thus, stimulation-induced memory enhancement may depend, at least in part or in certain contexts, on the ability of electrical neural stimulation to induce the development of functionally mature hippocampal neurons. The stimulation of neurogenesis with DBS has not yet been demonstrated in humans. Determining the optimal target location and stimulation parameters to treat $\mathrm{AD}$ with DBS, and the mechanisms responsible for its effects, will require further research.

\section{Summary and Conclusions}

Neurosurgeons may have an important role in the development of novel $\mathrm{AD}$ treatments. Over the past 40 years, various neurosurgical $\mathrm{AD}$ therapies have been at- tempted, including CSF shunting, intraventricular infusions, tissue grafting, gene therapy, and electrical neural stimulation. Among these, gene therapy and electrical neural stimulation, particularly fornix and NBM DBS, have emerged as viable, potentially beneficial treatment modalities for AD. These therapeutic modalities can influence neuronal activity within the pathological circuits associated with $\mathrm{AD}$ and may produce clinically useful improvements in cognitive function. Future studies investigating neurosurgical therapies for $\mathrm{AD}$ are warranted.

\section{Disclosure Statement}

Dr. Lozano owns intellectual property rights in the field of DBS for $\mathrm{AD}$.

\section{References}

1 Mayberg HS, Lozano AM, Voon V, McNeely HE, Seminowicz D, Hamani C, Schwalb JM, Kennedy SH: Deep brain stimulation for treatment-resistant depression. Neuron 2005; 45:651-660.

2 Lozano AM, Giacobbe P, Hamani C, Rizvi SJ, Kennedy SH, Kolivakis TT, Debonnel G, Sadikot AF, Lam RW, Howard AK, IlcewiczKlimek M, Honey CR, Mayberg HS: A multicenter pilot study of subcallosal cingulate area deep brain stimulation for treatment-resistant depression. J Neurosurg 2012;116:315322.

3 Denys D, Mantione M, Figee M, van den Munckhof P, Koerselman F, Westenberg H, Bosch A, Schuurman R: Deep brain stimulation of the nucleus accumbens for treatment-refractory obsessive-compulsive disorder. Arch Gen Psychiatry 2010;67:10611068.

4 Appenzeller O, Salmon JH: Treatment of parenchymatous degeneration of the brain by ventriculo-atrial shunting of the cerebrospinal fluid. J Neurosurg 1967;26:478-482.

$\checkmark 5$ Salmon JH: Senile and presenile dementia: ventriculoatrial shunt for symptomatic treatment. Geriatrics 1969;24:67-72.

-6 Silverberg GD, Levinthal E, Sullivan EV, Bloch DA, Chang SD, Leverenz J, Flitman S, Winn R, Marciano F, Saul T, Huhn S, Mayo M, McGuire D: Assessment of low-flow CSF drainage as a treatment for $\mathrm{AD}$ : results of a randomized pilot study. Neurology 2002;59: 1139-1145.

7 Silverberg GD, Mayo M, Saul T, Fellmann J, Carvalho J, McGuire D: Continuous CSF drainage in $\mathrm{AD}$ : results of a double-blind, randomized, placebo-controlled study. Neurology 2008;71:202-209.
8 Augustinsson LE, Blennow K, Blomstrand C, Brane G, Ekman R, Fredman P, Karlsson I, Kihlgren M, Lehmann W, Lekman A, Mansson JE, Ramstrom I, Wallin A, Wikkelso C, Gottfries CG, Svennerholm L: Intracerebroventricular administration of GM1 ganglioside to presenile Alzheimer patients. Dement Geriatr Cogn Disord 1997;8:26-33.

-9 Eriksdotter-Jönhagen M, Nordberg A, Amberla K, Backman L, Ebendal T, Meyerson B, Olson L, Seiger, Shigeta M, Theodorsson E, Viitanen M, Winblad B, Wahlund LO: Intracerebroventricular infusion of nerve growth factor in three patients with Alzheimer's disease. Dement Geriatr Cogn Disord 1998;9: 246-257.

10 Harbaugh RE: Intracerebroventricular bethanechol chloride administration in $\mathrm{Al}$ zheimer's disease. Ann NY Acad Sci 1988;531: 174-179.

11 Harbaugh RE, Reeder TM, Senter HJ, Knopman DS, Baskin DS, Pirozzolo F, Chui HC, Shetter AG, Bakay RA, Leblanc R, et al: Intracerebroventricular bethanechol chloride infusion in Alzheimer's disease. Results of a collaborative double-blind study. J Neurosurg 1989;71:481-486.

12 Harbaugh RE, Roberts DW, Coombs DW, Saunders RL, Reeder TM: Preliminary report: intracranial cholinergic drug infusion in patients with Alzheimer's disease. Neurosurgery 1984;15:514-518.

13 Penn RD, Martin EM, Wilson RS, Fox JH, Savoy SM: Intraventricular bethanechol infusion for Alzheimer's disease: results of double-blind and escalating-dose trials. Neurology 1988;38:219-222.

14 Read SL, Frazee J, Shapira J, Smith C, Cummings JL, Tomiyasu U: Intracerebroventricu- lar bethanechol for Alzheimer's disease. Variable dose-related responses. Arch Neurol 1990;47:1025-1030.

15 Seiger A, Nordberg A, von Holst H, Backman L, Ebendal T, Alafuzoff I, Amberla K, Hartvig P, Herlitz A, Lilja A, et al: Intracranial infusion of purified nerve growth factor to an Alzheimer patient: the first attempt of a possible future treatment strategy. Behav Brain Res 1993;57:255-261.

16 Svennerholm L, Brane G, Karlsson I, Lekman A, Ramstrom I, Wikkelso C: Alzheimer disease - effect of continuous intracerebroventricular treatment with GM1 ganglioside and a systematic activation programme. Dement Geriatr Cogn Disord 2002;14:128136.

17 Goldsmith HS: Treatment of Alzheimer's disease by transposition of the omentum. Ann NY Acad Sci 2002;977:454-467.

18 Rafael H, Mego R, Moromizato P, Espinoza M: Omental transplantation for Alzheimer's disease. Neurol India 2000;48:319-321.

19 Shankle WR, Hara J, Bjornsen L, Gade GF, Leport PC, Ali MB, Kim J, Raimo M, Reyes L, Amen D, Rudy L, O’Heany T: Omentum transposition surgery for patients with $\mathrm{Al}$ zheimer's disease: a case series. Neurol Res 2008;30:313-325.

20 Eriksdotter-Jönhagen M, Linderoth B, Lind G, Aladellie L, Almkvist O, Andreasen N, Blennow K, Bogdanovic N, Jelic V, Kadir A, Nordberg A, Sundstrom E, Wahlund LO, Wall A, Wiberg M, Winblad B, Seiger A, Almqvist P, Wahlberg L: Encapsulated cell biodelivery of nerve growth factor to the basal forebrain in patients with Alzheimer's disease. Dement Geriatr Cogn Disord 2012;33: $18-28$. 
21 Tuszynski MH, Thal L, Pay M, Salmon DP, U 33 Leon A, Dal Toso R, Presti D, Benvegnu D, HS, Bakay R, Patel P, Blesch A, Vahlsing HL, Ho G, Tong G, Potkin SG, Fallon J, Hansen L, Mufson EJ, Kordower JH, Gall C, Conner J: A phase 1 clinical trial of nerve growth factor gene therapy for Alzheimer disease. Nat Med 2005; 11:551-555.

22 Laxton AW, Tang-Wai DF, McAndrews MP, Zumsteg D, Wennberg R, Keren R, Wherrett J, Naglie G, Hamani C, Smith GS, Lozano AM: A phase I trial of deep brain stimulation of memory circuits in Alzheimer's disease. Ann Neurol 2010;68:521-534.

-23 Turnbull IM, McGeer PL, Beattie L, Calne D, Pate B: Stimulation of the basal nucleus of Meynert in senile dementia of Alzheimer's type. A preliminary report. Appl Neurophysiol 1985;48:216-221.

-24 Merrill CA, Jonsson MA, Minthon L, Ejnell $\mathrm{H}, \mathrm{H}$ CsS, Blennow K, Karlsson M, Nordlund A, Rolstad S, Warkentin S, Ben-Menachem E, Sjogren MJ: Vagus nerve stimulation in patients with Alzheimer's disease: additional follow-up results of a pilot study through 1 year. J Clin Psychiatry 2006;67:1171-1178.

-25 Sjogren MJ, Hellstrom PT, Jonsson MA, Runnerstam M, Silander HC, Ben-Menachem E: Cognition-enhancing effect of vagus nerve stimulation in patients with Alzheimer's disease: a pilot study. J Clin Psychiatry 2002;63: 972-980.

26 Fontaine D, Dueudon A, Lemaire JJ, Razzouk M, Viau P, Darcourt J, Robert P: Symptomatic treatment of memory decline in Alzheimer's disease by deep brain stimulation: a feasibility study. J Alzheimers Dis 2013;34:315323.

$\checkmark 27$ Adams RD, Fisher CM, Hakim S, Ojemann RG, Sweet WH: Symptomatic occult hydrocephalus with 'normal' cerebrospinal-fluid pressure. A treatable syndrome. $\mathrm{N}$ Engl J Med 1965;273:117-126.

28 Hulstaert F, Blennow K, Ivanoiu A, Schoonderwaldt HC, Riemenschneider M, De Deyn PP, Bancher C, Cras P, Wiltfang J, Mehta PD, Iqbal K, Pottel H, Vanmechelen E, Vanderstichele $\mathrm{H}$ : Improved discrimination of AD patients using $\beta$-amyloid $(1-42)$ and tau levels in CSF. Neurology 1999;52:1555-1562.

-29 Bartus RT, Dean RL 3rd, Beer B, Lippa AS: The cholinergic hypothesis of geriatric memory dysfunction. Science 1982;217:408-414.

- 30 Fischer W, Wictorin K, Bjorklund A, Williams LR, Varon S, Gage FH: Amelioration of cholinergic neuron atrophy and spatial memory impairment in aged rats by nerve growth factor. Nature 1987;329:65-68.

-31 Hefti F: Nerve growth factor promotes survival of septal cholinergic neurons after fimbrial transections. J Neurosci 1986;6:21552162.

- 32 Cannella MS, Oderfeld-Nowak B, Gradkowska M, Skup M, Garofalo L, Cuello AC, Ledeen RW: Derivatives of ganglioside GM1 as neuronotrophic agents: comparison of in vivo and in vitro effects. Brain Res 1990;513:286294.
Facci L, Kirschner G, Tettamanti G, Toffano G: Development and survival of neurons in dissociated fetal mesencephalic serum-free cell cultures. II. Modulatory effects of gangliosides. J Neurosci 1988;8: 746-753.

34 Skaper SD, Katoh-Semba R, Varon S: GM1 ganglioside accelerates neurite outgrowth from primary peripheral and central neurons under selected culture conditions. Brain Res 1985;355:19-26.

-35 Svennerholm L, Gottfries CG, Blennow K, Fredman P, Karlsson I, Mansson JE, Toffano G, Wallin A: Parenteral administration of GM1 ganglioside to presenile Alzheimer patients. Acta Neurol Scand 1990; 81:48-53.

36 Goldsmith HS, Duckett S, Chen WF: Prevention of cerebral infarction in the dog by intact omentum. Am J Surg 1975;130:317-320.

37 Goldsmith HS, Duckett S, Chen WF: Prevention of cerebral infarction in the monkey by omental transposition to the brain. Stroke 1978;9:224-229.

38 Goldsmith HS, Chen WF, Duckett SW: Brain vascularization by intact omentum. Arch Surg 1973;106:695-698.

39 Goldsmith HS, Saunders RL, Reeves AG, Allen $\mathrm{CD}$, Milne J: Omental transposition to brain of stroke patients. Stroke 1979;10:471472.

40 Goldsmith HS: Omental transposition for Alzheimer's disease. Neurol Res 1996;18:103108.

41 Goldsmith HS, Wu W, Zhong J, Edgar M: Omental transposition to the brain as a surgical method for treating Alzheimer's disease. Neurol Res 2003;25:625-634.

42 Goldsmith HS: A new approach to the treatment of Alzheimer's disease: the need for a controlled study. J Alzheimers Dis 2011;25: 209-212.

43 Oliveira AA Jr, Hodges HM: Alzheimer's disease and neural transplantation as prospective cell therapy. Curr Alzheimer Res 2005;2: 79-95.

44 Debinski W, Tatter SB: Convection-enhanced delivery to achieve widespread distribution of viral vectors: predicting clinical implementation. Curr Opin Mol Ther 2010;12: 647-653.

45 Eberling JL, Jagust WJ, Christine CW, Starr P, Larson P, Bankiewicz KS, Aminoff MJ: Results from a phase I safety trial of hAADC gene therapy for Parkinson disease. Neurology 2008;70:1980-1983.

46 LeWitt PA, Rezai AR, Leehey MA, Ojemann SG, Flaherty AW, Eskandar EN, Kostyk SK, Thomas K, Sarkar A, Siddiqui MS, Tatter SB, Schwalb JM, Poston KL, Henderson JM, Kurlan RM, Richard IH, Van Meter L, Sapan CV, During MJ, Kaplitt MG, Feigin A: AAV2GAD gene therapy for advanced Parkinson's disease: a double-blind, sham-surgery controlled, randomised trial. Lancet Neurol 2011; 10:309-319.
7 Tuszynski MH, U HS, Amaral DG, Gage FH: Nerve growth factor infusion in the primate brain reduces lesion-induced cholinergic neuronal degeneration. J Neurosci 1990;10: 3604-3614.

48 Folstein MF, Folstein SE, McHugh PR: 'Mini-mental state': a practical method for grading the cognitive state of patients for the clinician. J Psychiatr Res 1975;12:189198.

49 Rosen WG: A new rating scale for Alzheimer's disease. Am J Psychiatry 1984;141:13561364.

50 Bishop KM, Hofer EK, Mehta A, Ramirez A, Sun L, Tuszynski M, Bartus RT: Therapeutic potential of CERE-110 (AAV2-NGF): targeted, stable, and sustained NGF delivery and trophic activity on rodent basal forebrain cholinergic neurons. Exp Neurol 2008;211: 574-584.

51 Arvanitakis Z, Tuszynski M, Potkin S, Bartus $R$, Bennett D: A phase 1 clinical trial of CERE110 (AAV-NGF) gene delivery in Alzheimer's disease. Am Acad Neurol Ann Meet, Boston, 2007.

52 Wahlberg LU, Lind G, Almqvist PM, Kusk P, Tornoe J, Juliusson B, Soderman M, Sellden E, Seiger A, Eriksdotter-Jönhagen M, Linderoth B: Targeted delivery of nerve growth factor via encapsulated cell biodelivery in $\mathrm{Al}$ zheimer disease: a technology platform for restorative neurosurgery. J Neurosurg 2012; 117:340-347.

53 Groves DA, Brown VJ: Vagal nerve stimulation: a review of its applications and potential mechanisms that mediate its clinical effects. Neurosci Biobehav Rev 2005;29:493500.

54 Obeso JA, Guridi J, Rodriguez-Oroz MC, et al: Deep-brain stimulation of the subthalamic nucleus or the pars interna of the globus pallidus in Parkinson's disease. N Engl J Med 2001;345:956-963.

55 Deuschl G, Schade-Brittinger C, Krack P, et al: A randomized trial of deep-brain stimulation for Parkinson's disease. N Engl J Med 2006;355:896-908.

56 Follett KA, Weaver FM, Stern M, Hur K, Harris CL, Luo P, Marks WJ, Rothlind J, Sagher O, Moy C, Pahwa R, Burchiel K, Hogarth P, Lai EC, Duda JE, Holloway K, Samii A, Horn S, Bronstein JM, Stoner G, Starr PA, Simpson R, Baltuch G, De Salles A, Huang GD, Reda DJ: Pallidal versus subthalamic deep-brain stimulation for Parkinson's disease. N Engl J Med 2010;362: 2077-2091.

57 Kupsch A, Benecke R, Müller J, Trottenberg T, Schneider G-H, Poewe W, Eisner W, Wolters A, Müller J-U, Deuschl G, Pinsker MO, Skogseid IM, Roeste GK, VollmerHaase J, Brentrup A, Krause M, Tronnier V, Schnitzler A, Voges J, Nikkhah G, Vesper J, Naumann M, Volkmann J: Pallidal deepbrain stimulation in primary generalized or segmental dystonia. N Engl J Med 2006;355: 1978-1990. 
58 Schuurman PR, Bosch DA, Bossuyt PMM, 67 Nagaoka T, Katayama Y, Kano T, Kobayashi Bonsel GJ, van Someren EJW, de Bie RMA, Merkus MP, Speelman JD: A comparison of continuous thalamic stimulation and thalamotomy for suppression of severe tremor. $\mathrm{N}$ Engl J Med 2000;342:461-468.

59 Vidailhet M, Vercueil L, Houeto J-L, Krystkowiak P, Benabid A-L, Cornu P, Lagrange C, Tézenas du Montcel S, Dormont D, Grand S, Blond S, Detante O, Pillon B, Ardouin C, Agid Y, Destée A, Pollak P: Bilateral deep brain stimulation of the globus pallidus in primary generalized dystonia. N Engl J Med 2005;352: 459-467.

60 Weaver FM, Follett K, Stern M, Hur K, Harris C, Marks WJ, Rothlind J, Sagher O, Reda D, Moy CS, Pahwa R, Burchiel K, Hogarth P, Lai EC, Duda JE, Holloway K, Samii A, Horn S, Bronstein J, Stoner G, Heemskerk J, Huang GD: Bilateral deep brain stimulation versus best medical therapy for patients with advanced Parkinson disease: a randomized controlled trial. JAMA 2009;301: 63-73.

-61 Williams A, Gill S, Varma T, Jenkinson C, Quinn N, Mitchell R, Scott R, Ives N, Rick C, Daniels J, Patel S, Wheatley K: Deep brain stimulation plus best medical therapy versus best medical therapy alone for advanced Parkinson's disease (PD SURG trial): a randomised, open-label trial. Lancet Neurol 2010;9:581-591.

-62 Carlson JD, Cleary DR, Cetas JS, Heinricher MM, Burchiel KJ: Deep brain stimulation does not silence neurons in subthalamic nucleus in Parkinson's patients. J Neurophysiol 2010;103:962-967.

63 Clark KB, Smith DC, Hassert DL, Browning RA, Naritoku DK, Jensen RA: Posttraining electrical stimulation of vagal afferents with concomitant vagal efferent inactivation enhances memory storage processes in the rat. Neurobiol Learn Mem 1998;70:364-373.

-64 Fukuda M, Mentis MJ, Ma Y, Dhawan V, Antonini A, Lang AE, Lozano AM, Hammerstad J, Lyons K, Koller WC, Moeller JR, Eidelberg D: Networks mediating the clinical effects of pallidal brain stimulation for Parkinson's disease: a PET study of resting-state glucose metabolism. Brain 2001;124:16011609.

65 Hilker R, Voges J, Weisenbach S, Kalbe E, Burghaus L, Ghaemi M, Lehrke R, Koulousakis A, Herholz K, Sturm V, Heiss WD: Subthalamic nucleus stimulation restores glucose metabolism in associative and limbic cortices and in cerebellum: Evidence from a FDGPET study in advanced Parkinson's disease. J Cereb Blood Flow Metab 2004;24:7-16.

-66 Karimi M, Golchin N, Tabbal SD, Hershey T, Videen TO, Wu J, Usche JWM, Revilla FJ, Hartlein JM, Wernle AR, Mink JW, Perlmutter JS: Subthalamic nucleus stimulationinduced regional blood flow responses correlate with improvement of motor signs in Parkinson disease. Brain 2008;131:27102719.
$\mathrm{K}$, Oshima $\mathrm{H}$, Fukaya C, Yamamoto $\mathrm{T}$ : Changes in glucose metabolism in cerebral cortex and cerebellum correlate with tremor and rigidity control by subthalamic nucleus stimulation in Parkinson's disease: a positron emission tomography study. Neuromodulation 2007;10:206-215.

68 Seeley WW, Crawford RK, Zhou J, Miller BL, Greicius MD: Neurodegenerative diseases target large-scale human brain networks. Neuron 2009;62:42-52.

69 Greicius MD, Srivastava G, Reiss AL, Menon V: Default-mode network activity distinguishes Alzheimer's disease from healthy aging: evidence from functional MRI. Proc Natl Acad Sci USA 2004;101:4637-4642.

70 Chase TN: Regional cortical dysfunction in Alzheimer's disease as determined by positron emission tomography. Ann Neurol 1984; 15(suppl):S170-S174.

71 Silverman DHS, Small GW, Chang CY, Lu CS, de Aburto MAK, Chen W, Czernin J, Rapoport SI, Pietrini P, Alexander GE, Schapiro MB, Jagust WJ, Hoffman JM, WelshBohmer KA, Alavi A, Clark CM, Salmon E, de Leon MJ, Mielke R, Cummings JL, Kowell AP, Gambhir SS, Hoh CK, Phelps ME: Positron emission tomography in evaluation of dementia. J Am Med Assoc 2001;286:21202127.

72 Laxton AW, Lozano AM: DBS for the treatment of Alzheimer's disease and dementias. World Neurosurg 2013;80:S28, e1-e8.

73 Clark KB, Krahl SE, Smith DC, Jensen RA: Post-training unilateral vagal stimulation enhances retention performance in the rat. Neurobiol Learn Mem 1995;63:213-216.

74 Sackeim HA, Keilp JG, Rush AJ, George MS, Marangell LB, Dormer JS, Burt T, Lisanby $\mathrm{SH}$, Husain M, Cullum CM, Oliver N, Zboyan $\mathrm{H}$ : The effects of vagus nerve stimulation on cognitive performance in patients with treatment-resistant depression. Neuropsychiatry Neuropsychol Behav Neurol 2001;14: 53-62.

75 Schneider LS, Olin JT, Doody RS, Clark CM, Morris JC, Reisberg B, Schmitt FA, Grundman M, Thomas RG, Ferris SH: Validity and reliability of the Alzheimer's Disease Cooperative Study-Clinical Global Impression Of Change. The Alzheimer's Disease Cooperative Study. Alzheimer Dis Assoc Disord 1997; 11(suppl 2):S22-S32.

76 Freund H-J, Kuhn J, Lenartz D, Mai JK, Schnell T, Klosterkoetter J, Sturm V: Cognitive functions in a patient with Parkinson-dementia syndrome undergoing deep brain stimulation. Arch Neurol 2009;66:781-785.

77 Barnikol TT, Pawelczyk NBA, Barnikol UB, Kuhn J, Lenartz D, Sturm V, Tass PA, Freund $\mathrm{H}-\mathrm{J}$ : Changes in apraxia after deep brain stimulation of the nucleus basalis of Meynert in a patient with Parkinson dementia syndrome. Mov Disord 2010;25:1519-1520.

78 Tsivilis D, Vann SD, Denby C, Roberts N, Mayes AR, Montaldi D, Aggleton JP: A dis- proportionate role for the fornix and mammillary bodies in recall versus recognition memory. Nat Neurosci 2008;11:834-842.

-79 Browning PG, Gaffan D, Croxson PL, Baxter MG: Severe scene learning impairment, but intact recognition memory, after cholinergic depletion of inferotemporal cortex followed by fornix transection. Cereb Cortex 2010;20: 282-293.

80 Wilson CR, Baxter MG, Easton A, Gaffan D: Addition of fornix transection to frontaltemporal disconnection increases the impairment in object-in-place memory in macaque monkeys. Eur J Neurosci 2008;27: 1814-1822.

81 Mielke MM, Okonkwo OC, Oishi K, Mori S, Tighe S, Miller MI, Ceritoglu C, Brown T, Albert M, Lyketsos CG: Fornix integrity and hippocampal volume predict memory decline and progression to Alzheimer's disease. Alzheimers Dement 2012;8:105-113.

82 Hescham S, Lim LW, Jahanshahi A, Steinbusch HW, Prickaerts J, Blokland A, Temel Y: Deep brain stimulation of the forniceal area enhances memory functions in experimental dementia: the role of stimulation parameters. Brain Stim 2013;6:72-77.

83 Hamani C, McAndrews MP, Cohn M, Oh M, Zumsteg D, Shapiro CM, Wennberg RA, Lozano AM: Memory enhancement induced by hypothalamic/fornix deep brain stimulation. Ann Neurol 2008;63:119-123.

84 Ito K, Ahadieh S, Corrigan B, French J, Fullerton $\mathrm{T}$, Tensfeldt $\mathrm{T}$ : Disease progression meta-analysis model in Alzheimer's disease. Alzheimers Dement 2010;6:39-53.

85 Smith GS, Laxton AW, Tang-Wai DF, McAndrews MP, Diaconescu AO, Workman C, Lozano AM: Increased cerebral metabolism after one year of deep brain stimulation in $\mathrm{Al}$ zheimer's disease. Arch Neurol 2012;69: 1141-1148.

86 Laxton AW, Dostrovsky JO, Lozano AM: Stimulation physiology in functional neurosurgery; in Lozano AM, Gildenberg PL, Tasker RR (eds): Textbook of Stereotactic and Functional Neurosurgery. Berlin, Springer, 2009, pp 1383-1399.

87 Hamani C, Dubiela FP, Soares JCK, Shin D, Bittencourt S, Covolan L, Carlen PL, Laxton AW, Hodaie M, Stone SSD, Ha Y, Hutchison WD, Lozano AM, Mello LE, Oliveira MGM: Anterior thalamus deep brain stimulation at high current impairs memory in rats. Exp Neurol 2010;225:154-162.

88 Hamani C, Stone SS, Garten A, Lozano AM, Winocur G: Memory rescue and enhanced neurogenesis following electrical stimulation of the anterior thalamus in rats treated with corticosterone. Exp Neurol 2011;232:100104.

89 Stone SSD, Teixeira CM, DeVito LM, Zaslavsky K, Josselyn SA, Lozano AM, Frankland PW: Stimulation of entorhinal cortex promotes adult neurogenesis and facilitates spatial memory. J Neurosci 2011;31:1346913484. 
90 Berger TW, Hampson RE, Song D, Goonawardena A, Marmarelis VZ, Deadwyler SA: A cortical neural prosthesis for restoring and enhancing memory. J Neural Eng 2011;8: 046017.

91 Hampson RE, Gerhardt GA, Marmarelis V Song D, Opris I, Santos L, Berger TW, Deadwyler SA: Facilitation and restoration of cognitive function in primate prefrontal cortex by a neuroprosthesis that utilizes minicolumn-specific neural firing. J Neural Eng 2012; 9:056012.
92 Toda H, Hamani C, Fawcett AP, Hutchison WD, Lozano AM: The regulation of adult rodent hippocampal neurogenesis by deep brain stimulation. J Neurosurg 2008;108:132138.

93 Encinas JM, Hamani C, Lozano AM, Enikolopov G: Neurogenic hippocampal targets of deep brain stimulation. J Comp Neurol 2011; 519:6-20.

94 Derrick BE, York AD, Martinez JL Jr: Increased granule cell neurogenesis in the adult dentate gyrus following mossy fiber stimulation sufficient to induce long-term potentiation. Brain Res 2000;857:300-307.

$\checkmark 95$ Bruel-Jungerman E, Davis S, Rampon C, Laroche $S$ : Long-term potentiation enhances neurogenesis in the adult dentate gyrus. J Neurosci 2006;26:5888-5893.
96 Kitamura T, Saitoh Y, Murayama A, Sugiyama $\mathrm{H}$, Inokuchi K: LTP induction within a narrow critical period of immature stages enhances the survival of newly generated neurons in the adult rat dentate gyrus. Mol Brain 2010;3:1-8.

97 Chun SK, Sun W, Park JJ, Jung MW: Enhanced proliferation of progenitor cells following long-term potentiation induction in the rat dentate gyrus. Neurobiol Learn Mem 2006;86:322-329. 